\title{
THREE NEW NEOTROPICAL COPROPHAGOUS COLEOPTERA
}

\author{
By Renaud Paulian
}

Laboratoire d'Entomologie du Museum, Paris

The three new species described herein were sent me for study, together with a long series of unnamed coprophagous Coleoptera, mostly from the Neotropical region, by the $\mathrm{Mu}$ seum of Comparative Zoölogy of Harvard University. I am glad of this opportunity to thank Dr. P. J. Darlington, Jr., for the most interesting material he sent me and for his generosity in allowing me to keep paratypes of the new species.

Besides the new species, the material sent to me contained a long series of species of Canthidium. For the most part they were probably new, at least the species were neither in the Paris Museum, the British Museum, nor in my own collection. But it should be necessary, before describing new species of this genus, and of the closely allied Choeridium, to make a general revision of the species, as Harold's monographs are old and rather inadequate.

I take this opportunity to indicate that Uroxys productus Arrow, described from an old specimen without locality label, has been collected by Dufau (in coll. Fleutiaux) under stones at Trois Rivieres, Guadeloupe Is., West Indies. It appears to be rare and found only in unique specimens.

Canthon darlingtoni n. sp. (fig. 1, 2, 7)

Type: One specimen from Colombia: Santa Marta (P. J. Darlington). Museum of Comparative Zoölogy, no. 23,693.

Paratypes: A small series of specimens from the same locality in my collection and the Museum of Comparative Zoölogy.

Length : 4.75-5.5 mm., breadth: 3-3.5 mm.

Body convex, orbicular, very broad, shining but minutely shagreened above. Head brown-red; thorax pale testaceous 
with a large median anterior dark red patch; this patch touches the anterior margin, which is slightly darkened, as are also the lateral margins and the small lateral foveæ; middle of base with a vaguely rectangular dark patch. Elytra pale testaceous, with a dark transverse patch along the base; this patch broader at the sides, the sutural interstriæ darkened, a broad transverse patch about the middle, and on each elytron a small dark apical patch. Antennal club piceous, trophi yellow; legs red, with the femora largely testaceous in the middle, tarsi only slightly paler than the tibiæ. Underside red, with a small testaceous patch at the sides of the abdominal segments, this patch much larger on the last segment; pygidium reddish at the base, yellow at the apex.

Head rather broad, part of the eyes visible from above small and narrow; sides of the clypeus slightly raised, the anterior part impressed between the two anterior teeth; vertex with a slight median impression; anterior clypeal teeth curving upwards, rather long, parallel, rounded at apex; sides of the clypeus only very feebly sinuate between these teeth and the clypeogenal suture, which is very slightly marked; genal sutures feeble; genæ rounded, their greatest breadth at the middle. Head without any puncturation.

Thorax transverse, anterior angles acute, sides straight between those angles and the median angles, which are rounded and protrude very slightly behind. Posterior half of the sides gently rounded to the hind angles which are very slightly protruding behind, the sides of the base being feebly emarginated just inside these angles. Lateral margin a little more marked at the anterior angles; anterior margin complete; base gently rounded, with only a very slight angular protuberance in the middle; no scutellar impression. Puncturation very feeble and sparse, slightly stronger behind.

Elytral margins nearly straight, strongly curved behind; elytra convex, depressed along their apical margin; interstriæ flat, regular, only very sparsely and very feebly punctured; striæ distinct, not deep, distinctly punctured; scutellar impression very deep; elytral striæ ending anteriorly in small, basal, longitudinal foveæ; external epipleural margin very sharp, epipleura broad.

Pygidium nearly smooth, very short and broad, not margined at the base. No prosternal carina; mesosternum very 
short; metasternum with a broad, arcuate fovea, smooth. Anterior tibia broad, with three very sharp and long marginal teeth; median and posterior tibiæ slightly arcuate and strongly carinate. Tarsi long, equal to $3 / 4$ of the tibial length, compressed, metatarsus much shorter than the second joint. Hind femora slightly clavate, not margined.
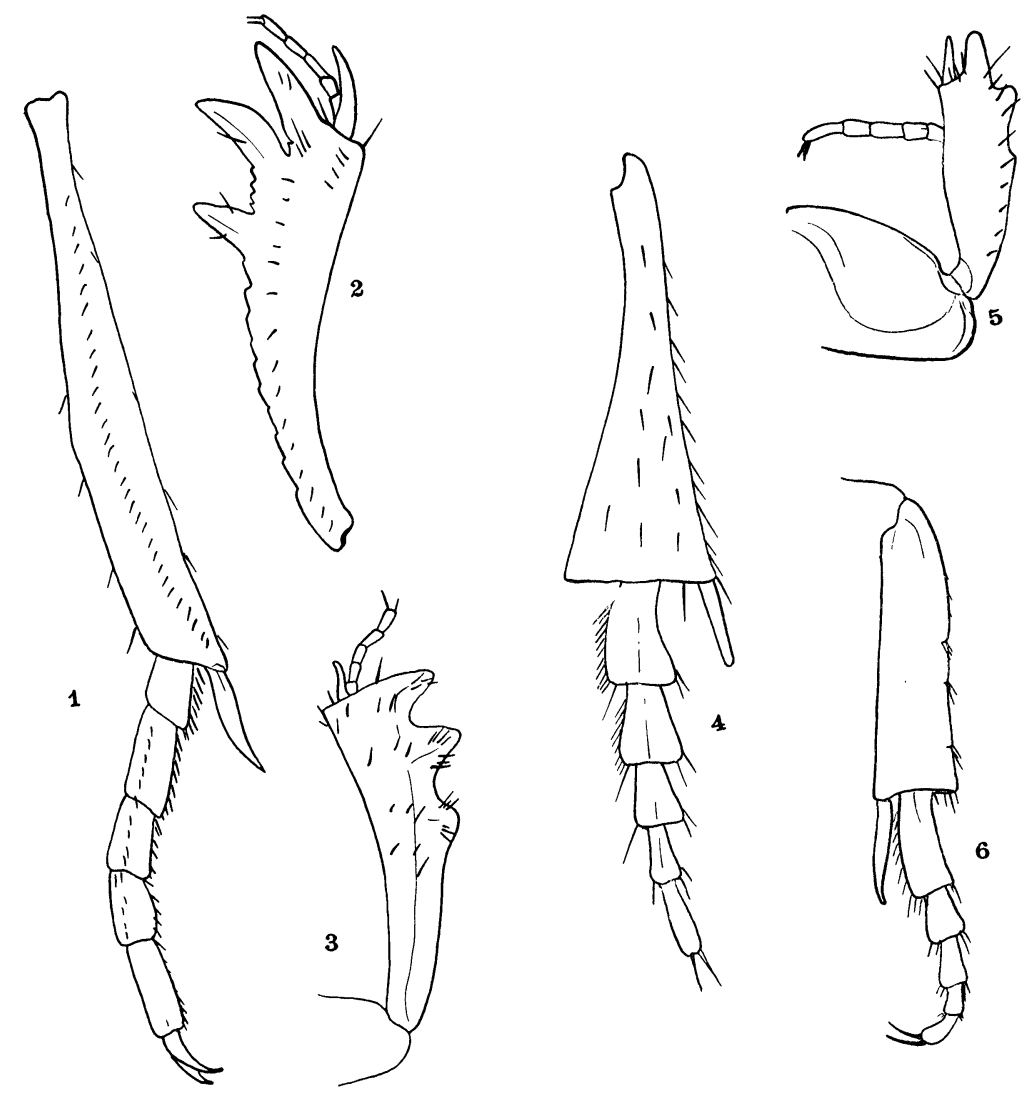

Fig. 1. Canthon darlingtoni n. sp., posterior leg.

Fig. 2. id., anterior leg.

Fig. 3. Uroxys pygmaeus, anterior leg.

Fig. 4. Bdelyrus bowditchi n. sp., posterior leg.

Fig. 5. Onthocharis panamensis n. sp., anterior leg.

Fig. 6. id., posterior leg. 
This very pretty little species belongs to the group cyanocephalus Har. but it is quite peculiar by its colour pattern and its broad form.

Bdelyrus bowditchi n. sp. (fig. 3, 4)

Type: From British Honduras: M-tee district, F. C. Bowditch Collection. Museum of Comparative Zoölogy no. 23,694.

Paratype: One specimen from the same locality in my collection.

Length: $5 \mathrm{~mm}$., breadth: $3.2 \mathrm{~mm}$.

Body rather convex, with curved sides; very dark brown, not shining, all the upper surface finely but distinctly shagreened.

Head very broad and short; part of the eyes visible from above very large, nearly round; clypeus impressed in front, with four teeth, the median teeth very close together, long, broad, upturned and rounded at tip; lateral teeth very short and blunt; the clypeogenal suture marked by a deep, rounded notch at the sides of the head; upper surface rather closely covered with middle-sized punctures.

Thorax very transverse, the anterior angles greatly protruding, rather blunt; the sides regularly curved, the greatest breadth being in the middle. Posterior angles straight; base gently curved and very feebly margined in the middle. Thorax with a rather deep longitudinal sulcus on each side of the disc. Puncturation of the thorax sparse and rather feeble, bearing (as do the elytra) short yellow setæ, erect and feebly clavate at tip.

Elytra short and broad, with rounded sides; the lateral margin is made by the eighth elytral interstria, which is strongly carinate up to the apex of the elytra. Humeral angle acute and protruding forwards; interstriæ slightly convex, with two irregular rows of setigerous punctures. Striæ feeble, cateniform, straight. Epipleural carinæ distinct.

Pygidium horizontal, short and small, with a strong annular groove. Mesosternum rather long. Prosternum strongly excavated under the front angles. Anterior tibiæ truncate at apex, short and broad ; posterior tibiæ greatly enlarged at the tip. Tarsal joints triangular. 
This new species appears at first sight as nearer to Canthochilum Chap. than to Bdelyrus Har. but the structure of the elytra ranges it decidedly in this last genus. $B$. bowditchi n. sp. is quite different from B. seminudus Bates (from Costa Rica and Ecuador) by the puncturation, the shagreened upper surface and the quadridentate clypeus. $B$. lagopus Har. from Brazil, the genotype, is unknown to me but nothing in its description differentiates it from $B$. seminudus, which, by the way, Bates placed in Aphengium.

Onthocharis panamensis n. sp. (fig. 5, 6, 8)

Type: From Panama Canal Zone: Barro Colorado Island, K. W. Cooper. Museum of Comparative Zoölogy no. 23,695.

Paratype: A specimen from the same locality in my collection.

Length: $3.5 \mathrm{~mm}$., breadth: $1.5 \mathrm{~mm}$.

Body parallel, elongate, very shining, very convex, metallic green.
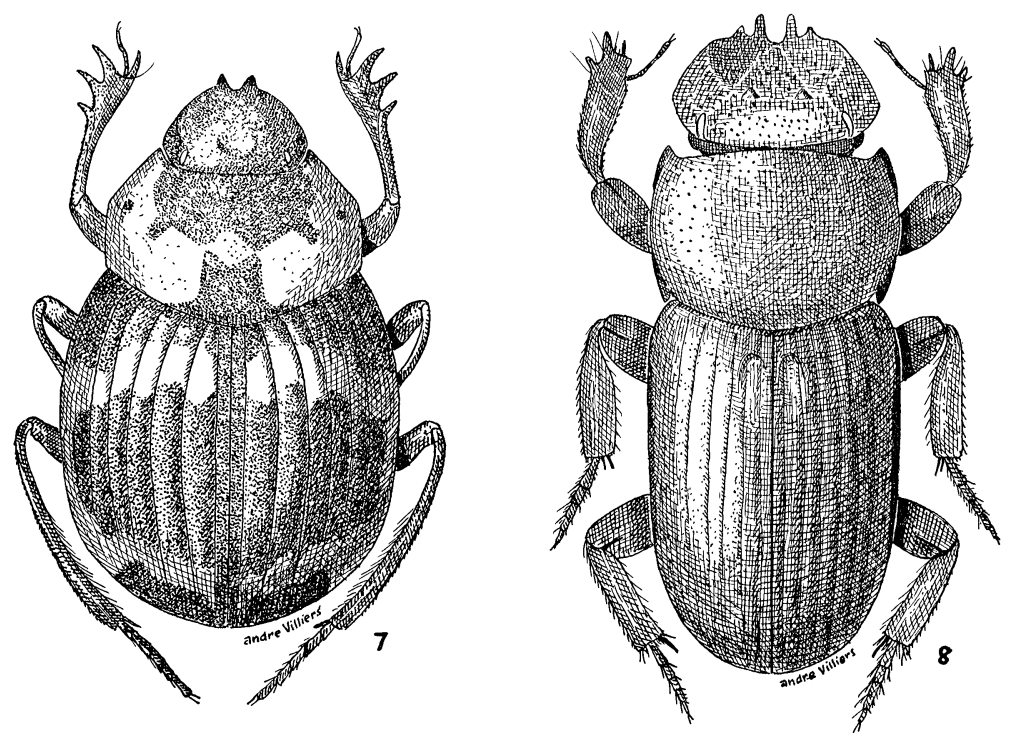

Fig. 7. Canthon darlingtoni n. sp.

Fig. 8. Onthocharis panamensis n. sp. 
Head very broad, clypeus depressed in front, sex-dentate, the lateral teeth very short, broad and rounded; the median teeth long, slender, rounded at the apex. Part of the eyes visible from above very narrow. Vertex with two small, rounded tubercles. All the head covered with a sparse and rather strong puncturation.

Thorax very convex, parallel-sided in the first four-fifths, slightly sinuate behind; posterior angles strongly protruding behind; base strongly emarginate inside the posterior angles, a strong oblique depression in front of this emargination; base gently and regularly rounded; disc of thorax with a short median longitudinal sulcus on the posterior half, this sulcus not touching the base; front angles acute; puncturation rather strong and sparse.

Elytra parallel, with a feeble scutellar impression, interstriæ slightly convex, very feebly and sparsely punctured; striæ rather strong, not closely punctured. Pygidium very convex and shining, rather long, strongly margined, the margin slightly angular in the middle, sparsely and finely punctured.

Front tibiæ broad, smooth, tridentate externally, the apical tooth in line with the lateral margin of the tibiæ. Posterior and median tibiæ compressed, parallel, broad. Posterior tarsi with the first joint nearly as long as the two following taken together, cylindrical. Abdomen nearly smooth. Prosternum with a long, transverse, slightly oblique carina; the front angles slightly excavated.

This new and very small species is quite distinct from the known species of the genus (and I have had the opportunity of studying in London the types of Westwood and Waterhouse) by the length of the tarsal joints and their cylindrical form. A general revision of the genus is much needed as many unidentified, and probably new, species are to be found in many collections and museums. 

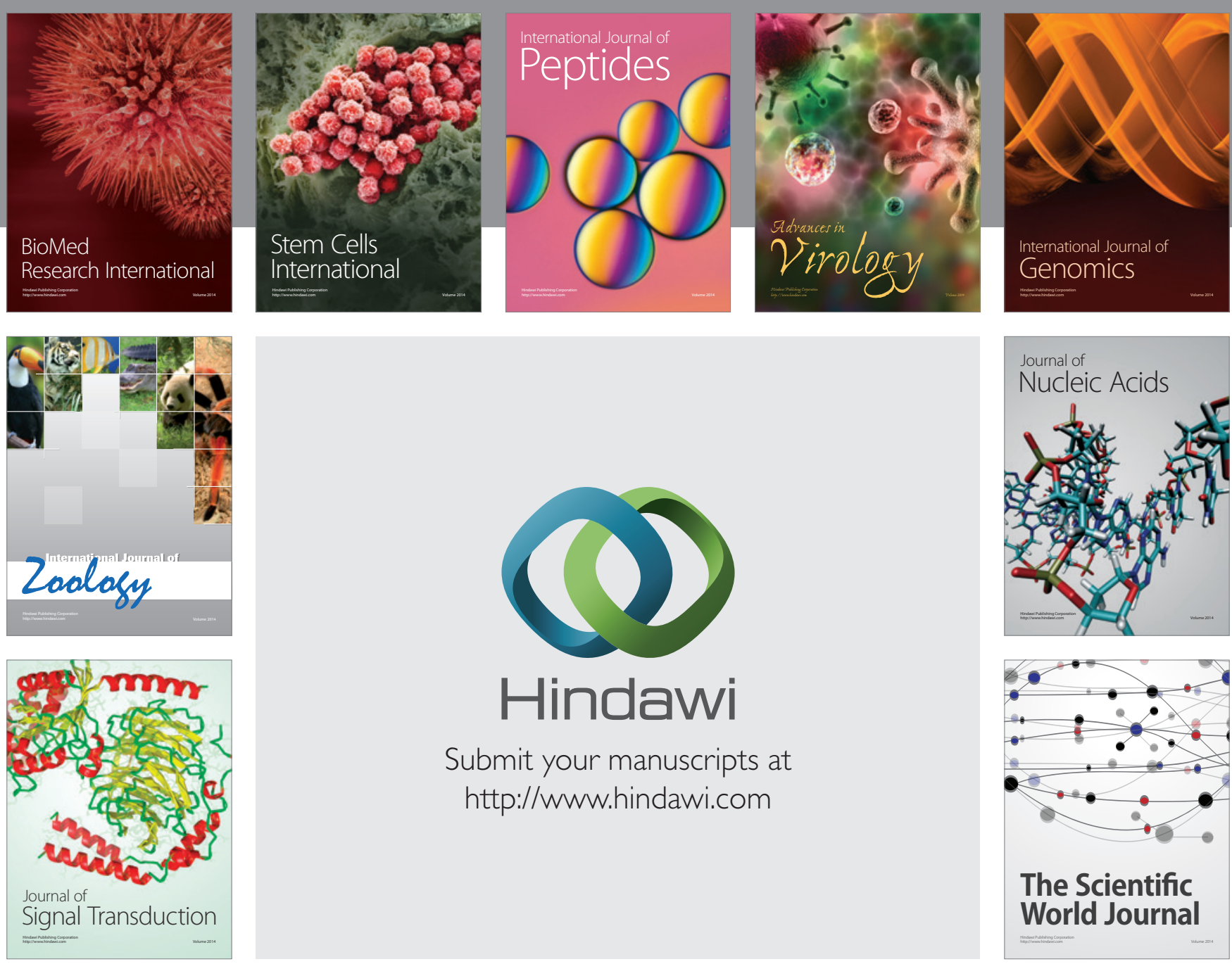

Submit your manuscripts at

http://www.hindawi.com
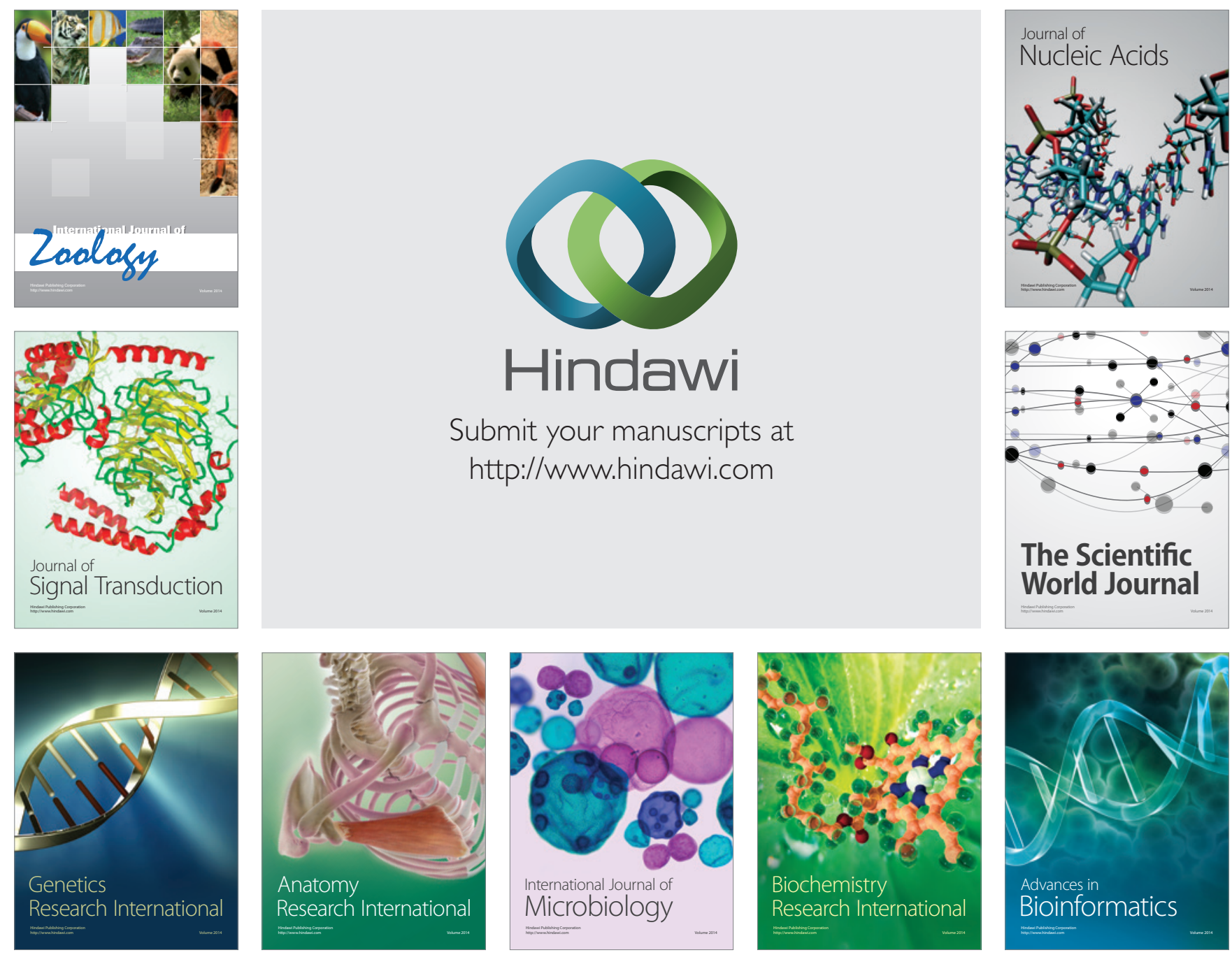

The Scientific World Journal
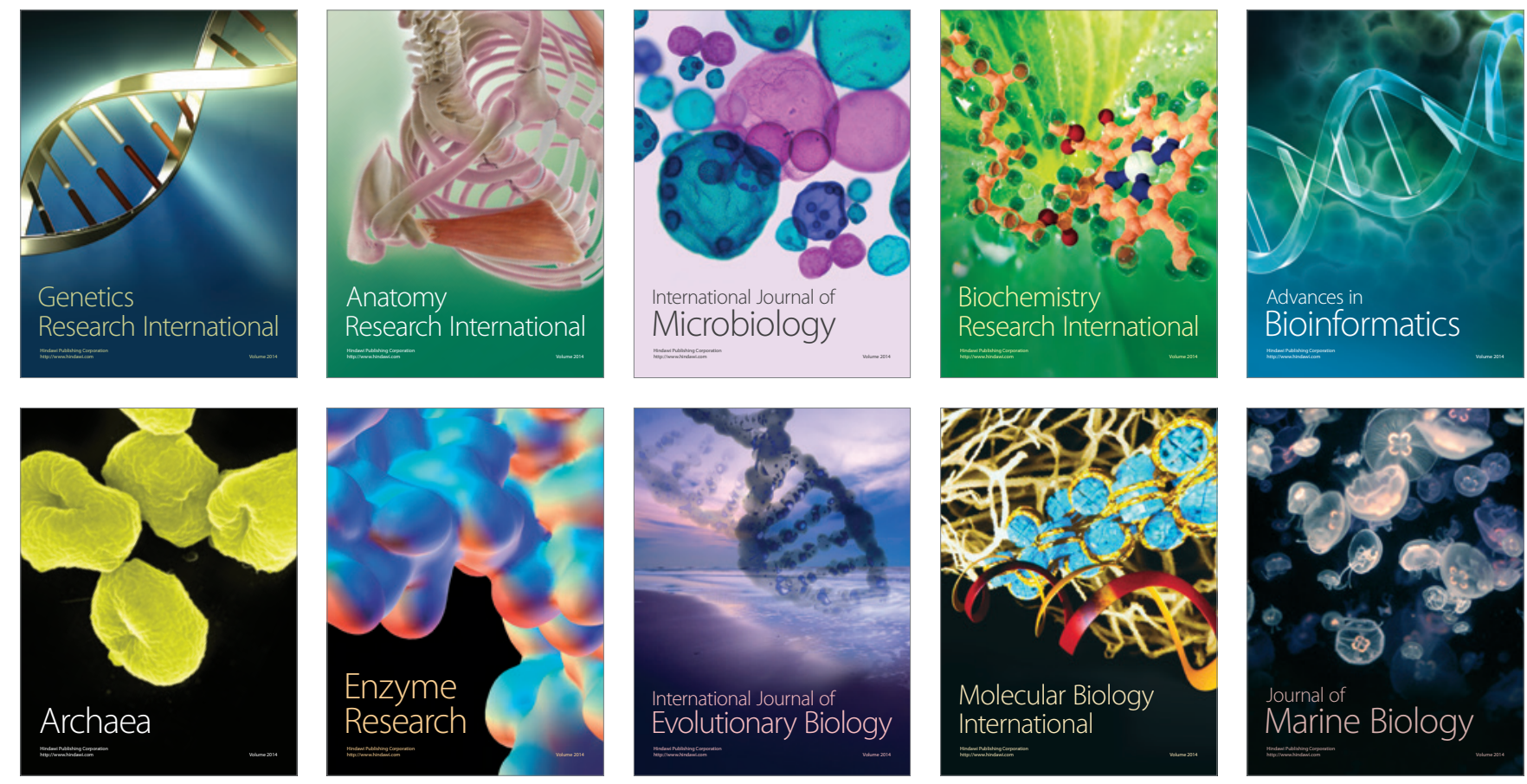